\title{
Perceived Organizational Support and Perceived Organizational Performance Mediated by Corporate Entrepreneurship
}

\author{
Massoud Alam Dad Mohammadia ${ }^{*}$, Mohd Noor Azli Ali Khanª, Meisam Karamia, Seyyed Reza Sadatifar ${ }^{\mathrm{b}}$ \\ ${ }^{a}$ Faculty of Management, University Teknologi Malaysia, 81310 UTM Johor Bahru, Johor, Malaysia \\ ${ }^{b}$ Faculty of Engeering, Esfrayen University of Technology, Esfarayen 9661998195, North Khorasan, Iran
}

*Corresponding author: d_masoud.alam@yahoo.com

\begin{abstract}
The blood of each economic is corporate entrepreneurship. Current research has investigated the link from the middle managers' viewpoint on the sector of Iranian technology generation between perceived organizational support and perceived organizational performance mediated by corporate entrepreneurship (CE). Scholars appraised vital internal organizational elements which impact middle managers in the CEE; like, work discretion, time availability, rewards, management support, and organizational boundaries. Corporate entrepreneurship (CE) has three is components; such as, proactiveness, risk taking, and product innovation. In result, perceived organizational implementation was assessed as: performance of innovation, market, and financial. In current study 500 validated questionnaires has been provided by middle managers. Finally, this research has present recommendations for better understanding of relation between perceived organizational support and perceived organizational performance mediated by corporate entrepreneurship.
\end{abstract}

Keywords: Perceived organizational support; corporate entrepreneurship; perceived organizational performance; middle managers; innovation

(C) 2016 Penerbit UTM Press. All rights reserved

\subsection{INTRODUCTION}

One of the important influential aspects on entrepreneurship is organizational elements. (Yang, Xu, \& Lu, 2012), related to studying the relationship between organizational structure and organizational entrepreneurship realized that there is not a significant relationship between organizational structure and organizational entrepreneurship and also there is a reverse relationship between components of organizational structure (Formality, Complexity and Centralization) and organizational entrepreneurship. Olmedo-Cifuentes and MartnezLeon (2012) defined educational, supportive, communication, managerial, business ability and policy making aspects as the most important influential elements on developing entrepreneurship within service, consulting, engineering, agricultural organizations in Iran. Tseng (2010) stated that organizational structure has a positive and significant impact on attitude of entrepreneurs. One of the influential organizational variables that can impact organizational entrepreneurship and perceived organizational performance is organizational culture (Lu, Lin, \& Tu, 2009). Organizational culture is a source that can have the fundamental role in attitude and forming entrepreneurial activities of small and medium businesses in Iran and it is the center of attention for many researchers (Armesh, Wei, Ghalandarzehie, Sargolzaie, \& Kahrazeh, 2014). J. L. Walls (2012) in their study about this subject, investigated about impacts of organizational culture including collaboration in entrepreneurial activities, compatibility, adjusting with modifications and organizational goal orientation, on organizational entrepreneurship in small and medium businesses in Iran. They found out that these variables have the positive and significant impact on components such as self-renewal, pioneer and new risky proceedings (B. Rettab, Ben Brik, \& Mellahi, 2009). The study developed by (Parast \& Adams, 2012) and it was about investigating the deterrent organizational elements of entrepreneurship in industrial company named North's Wood. The results revealed that conservative organizational culture (including variables of sufficient options for accomplishing job duties, welcoming the staff's opinion, clarifying organizational objectives, coordination among organizational departments, managerial support, organizational identity and compromising with conflict) has been the most important organizational entrepreneurship (Tseng, 2010).

In the current study, innovation, market and financial performance are related to corporate entrepreneurs with proactiveness positively that causing as the most essential association. Generally, perceived organizational performance is influenced by four out of five internal organizational factors obviously which they highlighted and affected positively. The most important factors among these four were rewards and organizational boundaries. Managers (middle) may take a further restricted hours structure to design or improve recent plans for their companies when organizations add work, documented working processes, standard operating procedures, and time constraints. With this implication, perceived organizational performance is negatively associated with only time availability. 


\subsection{LITERATURE REVIEW}

\section{Perceived Organizational Support}

Organizational support suggests that employees develop perceptions regarding the degree to which their organization values their contributions and the amount of concern exhibited towards their wellbeing (Rich, Lepine, \& Crawford, 2010). The underpinnings of perceived organizational support are derived from social exchange theory which was developed to explain interpersonal relationship maintenance in the context of the work environment. Once individuals assess the organizational support they receive, they act in accordance with a norm of reciprocity. Thus, when an individual perceives the organization to be supporting them by valuing their contribution to the organization and by indicating concern for their well-being, the individual will then feel obligated to be committed to the organization and will show this commitment through increased work efforts(Ring, 2011)

According to social exchange theory employees who perceive their organizational environment as supportive will feel obligated to reciprocate with behaviors that are beneficial to the organization (Shanock \& Eisenberger, 2006). From this viewpoint, it could be expected that perceived organizational support has a direct effect on corporate entrepreneurship, because positive feelings about the organization and its supportive nature could positively influence employees' receptivity towards the organization's efforts to introduce and implement corporate entrepreneurship (Holt, Rutherford, \& Kuratko, 2010). (Antoncic \& Hisrich, 2004) also suggest that organizational support characteristics such as management support, work discretion, rewards, time availability, and loose intra-organizational boundaries have been seen to be crucial organizational elements impacting corporate entrepreneurship.

This study has shown the utility of conceptualizing perceived organizational support as a factor that have a direct relationship with corporate entrepreneurship and indirectly effect on perceived organizational performance. For example,(Ambrose \& Schminke, 2003) found that corporate entrepreneurship affected the association between perceived organizational support and perceived organizational performance. (M. W. Rhoades et al., 2002) found that perceived organizational support influenced the relationship between commitment and organizational rewards, procedural justice, and supervisor support. Perceived organizational support has also been shown to alter the perceived supervisor support-voluntary turnover relationship (O'Connor et al., 2008).Finally, recent research has shown that procedural justice perceptions affect work outcomes via the influence of perceived organizational support (Masterson, Lewis, Goldman, \& Taylor, 2000). Based on these studies, it appears that perceived organizational support possesses great potential to influence many work relationships (Hochwarter, Kacmar, Perrewe, \& Johnson, 2003).

\section{Corporate Entrepreneurship (CE)}

Corporate entrepreneurship is defined as entrepreneurship activities within an existing organization. Corporate entrepreneurship refers not only to the creation of new business ventures, but also to other innovative activities and orientations such as development of new products, services, technologies, administrative techniques, strategies and competitive postures. In addition, corporate entrepreneurship is described as entrepreneurship within an organization which refers to emergent behavioral intentions and organizational behaviors that lead a deviation from the traditional forms of doing business. The term of $\mathrm{CE}$ which mention in the literature typically points out to corporate ventures that it referred to consider constituted organization in the ranges of profit ability, strategic renovation, innovation boosting, gaining awareness of future hire charge., and international achievement (Zahra, 1993). Understanding the middle management of demand from senior management of business initiatives and the capacities of operational level participants ,which can use entrepreneurial opportunities, effect on corporate enterprise initiatives at specific moments of development (Kearney, Hisrich, \& Antoncic, 2013; Kuratko, Hornsby, \& Covin, 2014; Zahra, 1993). CE initiatives are not as much as important for the major aims in top management's view of their daily occupational duties (M. H. Chen \& Cangahuala, 2010). For outside coming problems and internal tensions, the top managements are an "insurance" and a "security blanket" respectively that the outcome of the pressure to create opportunities for development (Dai \& Lin, 2012). There are three elements which are accepted by CE: (1) product innovation; (2) proactiveness; and (3) risk taking (Gomez-Haro, Aragon-Correa, \& Cordon-Pozo, 2011).

The ability of a firm to generate new outputs and adjust current ones is related to product innovation that helps to develop current or future demand (Gonzalez-Moreno \& Saez-Martinez, 2009). The first presenting new products, services or market technologies show the volume of a corporation in which they against of rivals that is the origin of the proactiveness (Hornsby, Kuratko, \& Zahra, 2002).

Lastly, if a firm stands to take corporate risks and improve plans by much undetermined consequences, be able to indicate as CE (Kearney, Hisrich, \& Antoncic, 2013). The base of CE depends on product innovation, proactiveness and risk taking (Dai \& Lin, 2012).

In a progressively competitive environment are purposed at rejuvenating, renovating, and redefining markets, organizations and industries which are cantered by CE. The benefit of using CE as the internal corporate spark for the companies is as a catalyst for the competitive advantage and to assist them preserve their status with a new essence of superior competition.(Gomez-Haro et al., 2011). This occurrence is categorized to at minimum four subtitles including: (1) sustained regeneration; (2) organizational rejuvenation; (3) strategic renovation; and (4) domain redefinition (M. H. Chen \& Cangahuala, 2010). The study about organizational factors that increase or prevent corporate entrepreneurial activities has done to have a successful performance of a company (Gomez-Haro et al., 2011; Gonzalez-Moreno \& SaezMartinez, 2009)

There are a few of the key variables that might have an impact on CE, for instance: stimulus and control systems, company culture, organizational structure and managerial support which have recognized by several researchers (Hornsby et al., 2002). The significance of these factors individually or in combination are clear in the direction of vital precursors for the CE attempt to generate an investment creativity due to their influence on the indoor location that identifies the attention and the advocacy of the entrepreneurship invention in a constituted firm (Kuratko, Hornsby, \& Covin, 2014). The type of CE activities is affected distinctly by internal elements which it has in an organization (Kearney et al., 2013).

The significance of middle management in augmenting and nurturing such independent manner in their classify and also in increasing the CE perfect is identified by many researchers (Dai \& Lin, 2012; Gomez-Haro et al., 2011). In this regard, the main of this subject has focused primarily on its essence, however to prepare a special directory that middle management might play as to the role was unsuccessful (Hornsby et al., 2002). However, some factors that might affect middle managers which are described by several researchers, 
the global agreed to be taken into reason the significance of increasing CE attempts is not available (Dai \& Lin, 2012). Though, At least five basic factors gained from recent research on the subject which appears to converge (M. H. Chen \& Cangahuala, 2010).

Management support is the first factor which is connected to top management's advocate of firm creativities to simplify and increase entrepreneurial acting (Y. Chen, Tang, Jin, Xie, \& Li, 2014). By preparing the essential resources or skilfulness or by institutionalizing the entrepreneurial action, the management can support and even defend inventive opinions in several shapes within the enterprise and its process systems (Dai \& Lin, 2012). The second factor is the reward which is the significant element that shows the proper use of a reward method (Ford, Garnsey, \& Probert, 2010). Hence, theoretician believed that an efficient structure enhance entrepreneurial activity that notice aims, feedback and highlighting, on individual obligation and motivations according to the outcome (Gonzalez-Moreno \& SaezMartinez, 2009). The middle management's willingness is also enhanced by using the proper rewards to get risks relevant to the firm's activities (Haar \& White, 2013). The time availability is the third factor which is linked to a resource (involving time) and their availability for enterprise activity. Therefore, for inventive activities, workers have to perceive the availability of resources (Hayton, 2005). In general, conducts leading to experimentation and take risk behaviors can due to the lake of resource, whereas these must result in inventive activities (Kearney et al., 2013). The presence of an organization support structure is named as organizational boundaries which is the fourth factor (Kuratko et al., 2014). The opinions are evaluated, selected and applied by the administrative mechanisms which are prepared in this structure (Martin-Rojas, Garcia-Morales, \& Bolivar-Ramos, 2013). The last one (the factor number 5) is named as work discretion which is the element of the take risks and refer to middle management which is linked with the approval of risks and acceptance to take when this occurs ("Evolving Corporate Entrepreneurship Strategy: Technology Incubation at Philips," 2010).

Top management support for CE, rewards and availability of resources, organizational structure and boundaries, risk taking which are the five internal factors as an explorative survey in a conceptual method for supporting an internal environment CE as the requirement (Azulay, Lerner, \& Tishler, 2002). Nevertheless, these factors deducted into three after empirical analysis completed and proved which including: directorial support, organizational structure, and reward and resource availability (M. H. Chen \& Cangahuala, 2010; Y. Chen et al., 2014). This study demonstrated the necessity for further study interested in five inner organizational elements assumption that instigate entrepreneurial action and also is not supporting the mentioned complete pattern design (Dai \& Lin, 2012; Ford et al., 2010; Gomez-Haro et al., 2011; Gonzalez-Moreno \& Saez-Martinez, 2009; Haar \& White, 2013; Hayton, 2005).

\section{The Middle Managers Role in Company}

\section{Entrepreneurship and Perceived Organizational Performance}

The key sources of ideas in an organization are attributed to middle managers, not to top managers (M. H. Chen \& Cangahuala, 2010). 'Inventors of the aim and problems of the condition quo' is the role of top managers while middle managers are the orchestrators and more junior managers are the entrepreneurs (Hinz \& Ingerfurth, 2013; Leitao \& Franco, 2011).

By the current organization's core competences and without breaking links, corporate entrepreneurs must expand its capabilities (Handfield, Petersen, Cousins, \& Lawson, 2009). The resolution of the capability-rigidity paradox is done by middle-managers who are the locus of CE Integrating perceptions from these two diverse sources (Handfield et al., 2009) lead to developing a conceptual framework (J. A. Felicio, Goncalves, \& Goncalves, 2013). The validation of organizational beliefs originated in the subjectivism, empiricism and pragmatism that knowledge theory emphasizes its significance (M. H. Chen \& Cangahuala, 2010). The network theory, which is a source for enhanced opportunity recognition, prepares vision interested in what way company entrepreneurs can utilize their exclusive social associations (J. A. Felicio et al., 2013).

A number of influential writers point out that middle managers are influential in promoting CE because they link the operational and strategic elements of a firm's activities (Handfield et al., 2009). There are studies that have been at the forefront of attempts to integrate CE with strategic management (Hinz \& Ingerfurth, 2013; Leitao \& Franco, 2011). The authors claimed that Innovation, organizational networks, internationalization, organizational learning, top management teams and governance, growth and flexibility are six points "intersection", which remainders undeveloped in evaluation to strategic management's comparative maturity that is the study of entrepreneurship (M. H. Chen \& Cangahuala, 2010).

The responsibility of involving internal rather than external activities is with Boundary spanners (J. A. Felicio et al., 2013). There are number of interactions effects on the efficiency of boundary spanners that they have with players as of other purposes or departments (Handfield et al., 2009). Managers are progressively wanted and expected to prevail over organizational boundaries and handling the change of both groups and teams as hierarchy is weakened and authority devolved (Hinz \& Ingerfurth, 2013). Generally, listening, communicating, negotiating team-building, facilitating, and conflict resolution are the expansion of a new set of soft, interpersonal skills as needed (J. A. Felicio et al., 2013; Handfield et al., 2009).

Surely, the most related to Caldwell's fourfold classification is the "the model of change management" which concentrations on the character of middle managers in the construction of strategic change (Hinz \& Ingerfurth, 2013). The principal activities undertaken by corporate entrepreneurs included strategic reformulation, reorganization and organizational change (M. H. Chen \& Cangahuala, 2010). To extend the model of ACAP (Absorptive Capacity), these three main roles-gatekeepers, boundary spanners and change agents and also strategic selections applied by elder (senior) directors are developed by Zahra and George (J. A. Felicio et al., 2013).

Distinct features of middle managers' contributions to entrepreneurship have conversed by many researchers (Handfield et al., 2009; Hinz \& Ingerfurth, 2013; Leitao \& Franco, 2011). The contributions of middle managers to a company's strategy were studied by another research (M. H. Chen \& Cangahuala, 2010; J. A. Felicio et al., 2013) that is intimately connected to CE. The significance of social capital due to encourages employees to be risk taking, without fear for their jobs or celebrity (M. H. Chen \& Cangahuala, 2010). The innovative procedure in a constituted company was as the precious role and essential characters of middle managers which were recognized the first byJ. A. Felicio et al. (2013). The significance of middle managers in increasing and sustaining innovations has conversed by researchers from the international business discipline (Handfield et al., 2009; Hinz \& Ingerfurth, 2013).

"The rising notice in the survey of entrepreneurship be present a reaction to the acceptance that such action is able to result in betterquality performance in constituting organizations" is recommended byLeitao and Franco (2011). The principal factor to achieve competitive benefit and accordingly superior financial rewards is CE which is proposed by Leitao and Franco (2011). In the same way, 
Handfield et al. (2009) suggest that undertaking CE activities improves a company's financial performance. CE has a helpful effect on financial measures of company performance (J. A. Felicio et al., 2013; Handfield et al., 2009). CE may be a normally efficient means to make better long-term company financial operation that has a tendency to be relatively low in the early years and rises with time that is the influence on performance (M. H. Chen \& Cangahuala, 2010; Hinz \& Ingerfurth, 2013; Leitao \& Franco, 2011). After going deep through the literature review, the study structure is displayed in Fig. 1. Three parts in this structure including Corporate Entrepreneurs' characteristics (independent variable), Corporate Entrepreneurial (independent variable) and perceived organizational performance (dependent variable)

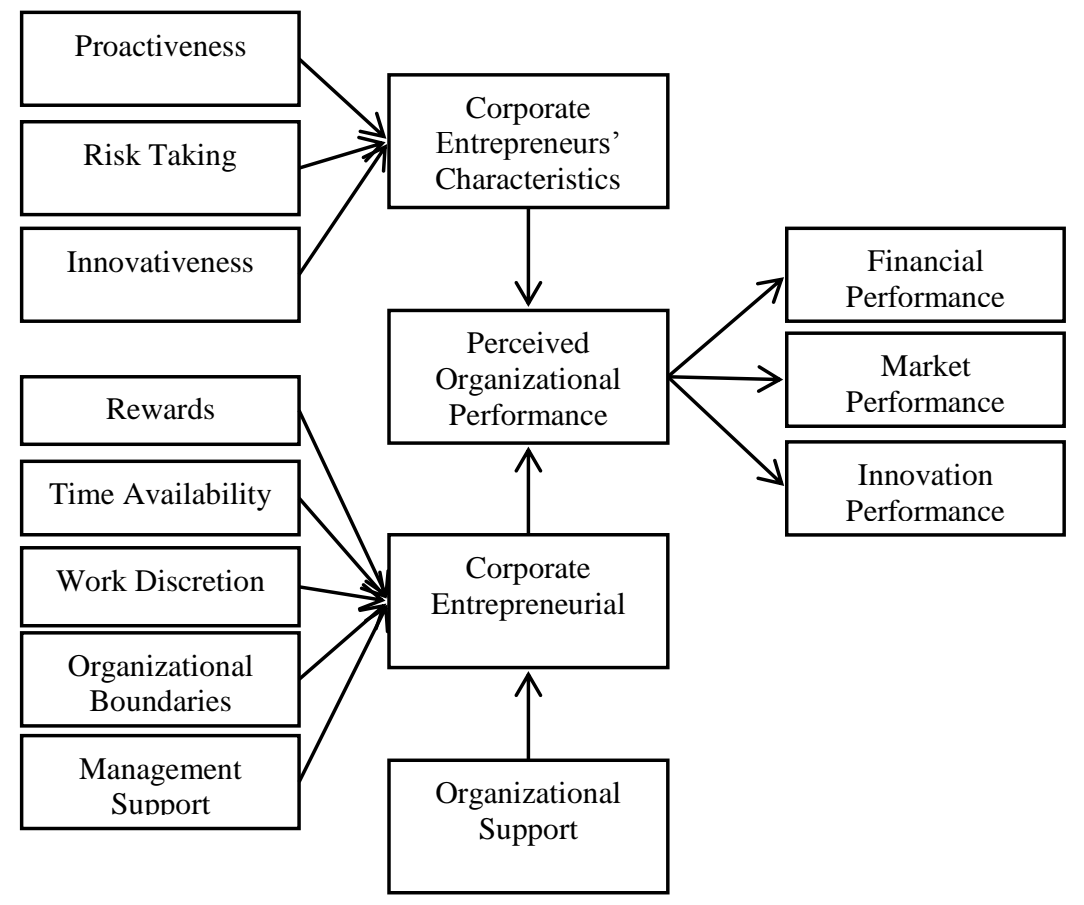

Figure 1 The research framework

\subsection{RESEARCH HYPOTHESES}

The precise role and essential characters of middle managers in the invention procedure in a funded corporation was identified by ( $\mathrm{J}$ Augusto Felicio, Couto, \& Caiado, 2013) whereas he was among the early researchers. An environment can be formed by middle managers in their relevant section or affiliated companies where the actions such as innovations and entrepreneurial flourish (Handfield et al., 2009). Successively, one of the advantages of this environment is that, multinationals are allowed to invest in the exclusive exist capitals in their diverse bazaar and be accountable to their clients effectually (Hinz \& Ingerfurth, 2013). The current study has present a new research proposed model which shown that the link from the middle managers' viewpoint on the sector of Iranian technology generation between perceived organizational support and perceived organizational performance mediated by corporate entrepreneurship. In this study, measure of Perceived Organizational Support (Eisenberg et al., 1998), (L. Rhoades, Eisenberger, \& Armeli, 2001), (Zhao et al., 2010) had 8 items. Therefore, This phrase"The rising notice in the survey of entrepreneurship be present a reaction to the acceptance that such action is able to result in enhanced operation in constructed organizations" is proposed byLeitao and Franco (2011). A positive effect on financial measures of firm performance is created by CE as propose by (Handfield et al., 2009). (1) proactiveness; (2) risk taking; and (3) product innovation are encompassing three related components as CE that is offered by Leitao and Franco (2011). Consequently, hypothesis 1 is suggested as:

H1: Perceived Organizational Support have a positive relationship with corporate entrepreneurship.

H2: Company entrepreneurs' features are a positive relationship with perceived organizational performance.

H2a: Company entrepreneurs with proactive characteristics are a positive relationship with perceived organizational performance (Innovation, Market and Financial).

H2b: Company entrepreneurs with risk taking characteristics are a positive relationship with perceived organizational performance (Innovation, Market and Financial).

H2c: Company entrepreneurs with innovativeness are a positive relationship with perceived organizational performance (Innovation, Market and Financial).

Study obviously displays which the types of CE activities a company pursues is affected by internal organizational elements. (1) Management support; (2) Work discretion; (3) Rewards; (4) Time availability; and (5) Organizational boundaries are five factors which Hornsby, Chao, Cheng, and Zheng (2011) had the same idea about them. Hence, hypothesis 2 is suggested as: 
H3: Company Entrepreneurial are a positive relationship with perceived organizational performance.

H3a: Management support is a positive relationship with perceived organizational performance.

$\mathrm{H} 3 \mathrm{~b}$ : Work discretion is a positive relationship with perceived organizational performance.

H3c: Rewards are a positive relationship with perceived organizational performance.

H3d: Time availability is a positive relationship with perceived organizational performance.

$\mathrm{H} 23$ : Organizational boundaries are a positive relationship with perceived organizational performance.

\subsection{METHODOLOGY}

\subsection{Sample And Data Collection}

In this research, the collection of data was done via mail review from companies middle managers recorded in Iran's highest 1000 manufacturing sector, highest 487 service company and highest 100 financial firm in 2014. Finally, 730 questionnaires out of 4,761 total, which send out, were returned and the amount of 21.52 percent of the rate of response was validated. Totally, 500 questionnaires from the Iranian technology manufacturing sector have been chosen by scholars.

\subsection{Measures}

The measures for the development of the company entrepreneurs, and the corporate entrepreneurial utilizing a 5-point Likert scale ranging from 1 to 5 (extremely disagree to extremely agree) according Choi and Yu (2014) for the corporate entrepreneurs' and on Fang, Huang, and Huang (2010)for the corporate entrepreneurial. The measures of perceived organizational performance were developed using a 7-point Likert scale ranging from 1 to 7 (extremely disagree to extremely agree) according le Roux (2014).

\subsection{RESULTS}

\subsection{Descriptive Analysis of Demographic Data (N=500)}

Table 1 Demographic information of over-all respondents.

\begin{tabular}{|c|c|c|c|}
\hline Demography Data & Descriptive & Frequency & Valid Percentage \\
\hline \multirow{3}{*}{ Gender } & Male & 403 & 80.60 \\
\hline & Female & 86 & 17.20 \\
\hline & Missing Value & 11 & 2.20 \\
\hline \multirow{6}{*}{ Education } & High School & 10 & 2.00 \\
\hline & College & 86 & 17.20 \\
\hline & University & 185 & 37.00 \\
\hline & Master & 189 & 37.80 \\
\hline & Doctoral & 26 & 5.20 \\
\hline & Missing Value & 4 & 0.80 \\
\hline \multirow{5}{*}{ Age } & Under 30 & 38 & 7.60 \\
\hline & $31-40$ & 211 & 42.20 \\
\hline & $41-50$ & 181 & 36.20 \\
\hline & Over 51 & 64 & 12.80 \\
\hline & Missing Value & 6 & 1.20 \\
\hline \multirow{7}{*}{ Department } & RD & 241 & 48.20 \\
\hline & Manufacture & 18 & 3.60 \\
\hline & Marketing & 163 & 32.60 \\
\hline & Human Resource & 22 & 4.40 \\
\hline & Finance & 14 & 2.80 \\
\hline & Others & 40 & 8.00 \\
\hline & Missing Value & 2 & 0.40 \\
\hline \multirow{7}{*}{ Profession } & Management & 211 & 42.20 \\
\hline & Engineering & 250 & 50.00 \\
\hline & Humanity & 4 & 0.80 \\
\hline & Law & 4 & 0.80 \\
\hline & Medicine & 5 & 1.00 \\
\hline & Others & 23 & 4.60 \\
\hline & Missing Value & 3 & 0.60 \\
\hline \multirow{6}{*}{ Work experiences } & Under 5 & 47 & 9.40 \\
\hline & bet $5 \& 10$ & 108 & 21.60 \\
\hline & bet $11 \& 15$ & 113 & 22.60 \\
\hline & bet $16 \& 20$ & 95 & 19.00 \\
\hline & Over 20 & 113 & 22.60 \\
\hline & Missing Value & 24 & 4.80 \\
\hline \multirow{6}{*}{ Years of Current Work } & Under 5 & 183 & 36.60 \\
\hline & bet $5 \& 10$ & 138 & 27.60 \\
\hline & bet $11 \& 15$ & 87 & 17.40 \\
\hline & bet $16 \& 20$ & 41 & 8.20 \\
\hline & Over 20 & 48 & 9.60 \\
\hline & Missing Value & 3 & 0.60 \\
\hline
\end{tabular}




\subsection{Factor and Reliability Analysis}

\subsubsection{Corporate Entrepreneurs' Characteristics}

Three components extracted by element extraction via a primary ingredient analysis after element rotation. The ingredients including: (1) proactiveness (2) innovativeness (3) and risk taking. The rotated component matrix is shown in Table 2.

Table 2 Factor analysis results by corporate entrepreneur characteristics

\begin{tabular}{|c|c|c|c|c|}
\hline Items & Questions & F1 & $\mathrm{F} 2$ & F3 \\
\hline \multirow[t]{2}{*}{ Innovativeness } & $\begin{array}{l}\text { I try to use new methods to do things and like the innovation } \\
\text { projects. }\end{array}$ & .825 & .253 & .145 \\
\hline & $\begin{array}{l}\text { I am at all times, adapting myself to the change of environment } \\
\text { and will not block by normal regulation. }\end{array}$ & .863 & .126 & .091 \\
\hline \multirow[t]{2}{*}{ Risk Taking } & I have support the high risk projects and high return. & .198 & .814 & -.023 \\
\hline & I do the ambiguity, risk, and uncertainty. & .001 & .846 & .071 \\
\hline \multirow[t]{5}{*}{ Proactiveness } & $\begin{array}{l}\text { I have the greater sensitivity on the competitors, products data, and } \\
\text { marketing. }\end{array}$ & .187 & .031 & .823 \\
\hline & $\begin{array}{l}\text { I attempt to be the most important products then competitors and } \\
\text { also focus on technology development. }\end{array}$ & .212 & .042 & .845 \\
\hline & Eigenvalues & 2.295 & 1.278 & .813 \\
\hline & Cumulative (\%) & 38.53 & 60.32 & 73.12 \\
\hline & Cronbach's Alpha & .71 & .597 & .621 \\
\hline
\end{tabular}

\subsubsection{Corporate Entrepreneurial}

In this study, researchers have extracted five components called as: (1) time availability (2) management support (3) organizational boundaries (4) rewards and (5) work discretion and the rotated component matrix are show in Table 3.

Table 3 Factor analysis results for variables of corporate entrepreneurial environment

\begin{tabular}{|c|c|c|c|c|c|c|}
\hline Items & Questions & F1 & F2 & F3 & F4 & F5 \\
\hline \multirow{4}{*}{$\begin{array}{l}\text { Organizational } \\
\text { Boundaries }\end{array}$} & $\begin{array}{l}\text { The present organization supports several } \\
\text { experimental and small plans comprehend that some } \\
\text { will undoubtedly fail. }\end{array}$ & .821 & .1 & .212 & .167 & -.02 \\
\hline & $\begin{array}{l}\text { Individual risk takers are often recognized for their } \\
\text { willingness to champion new projects, whether } \\
\text { eventually successful or not. }\end{array}$ & .875 & .076 & .165 & .176 & .156 \\
\hline & $\begin{array}{l}\text { People are often encouraged to take calculated risks } \\
\text { with new ideas around here. }\end{array}$ & .843 & .086 & .086 & .056 & -.09 \\
\hline & $\begin{array}{l}\text { Our company is fast to utilize developed work } \\
\text { methods that are improved by employees. }\end{array}$ & .814 & .087 & .123 & .188 & -.05 \\
\hline \multirow{5}{*}{ Management Support } & $\begin{array}{l}\text { I clearly know what level of work performance is } \\
\text { expected from me in terms of amount, quality, and } \\
\text { timeliness of output. }\end{array}$ & .075 & .654 & .375 & .286 & -.06 \\
\hline & $\begin{array}{l}\text { In the past three months, I have always followed } \\
\text { standard operating procedures or practices to do my } \\
\text { major tasks. }\end{array}$ & .075 & .811 & .045 & .053 & .167 \\
\hline & $\begin{array}{l}\text { We have the documental working process in the } \\
\text { company. }\end{array}$ & .085 & .803 & .076 & -.01 & -.05 \\
\hline & $\begin{array}{l}\text { My job description clearly specifies the standards of } \\
\text { performance on which my job is evaluated. }\end{array}$ & .053 & .811 & -.05 & .034 & .156 \\
\hline & There is little uncertainty in my job. & .175 & .624 & .004 & .145 & -.32 \\
\hline \multirow{3}{*}{ Work Discretion } & I have much autonomy to decide what I do on my job. & .234 & .063 & .814 & .153 & .003 \\
\hline & $\begin{array}{l}\text { It is basically my own responsibility to decide how my } \\
\text { job gets done. }\end{array}$ & .165 & .076 & .785 & .134 & .034 \\
\hline & $\begin{array}{l}\text { This organization make available freedom to use my } \\
\text { own judgment. }\end{array}$ & .178 & .088 & .798 & .154 & -.03 \\
\hline \multirow[t]{3}{*}{ Rewards } & $\begin{array}{l}\text { My manager would tell his boss if my work was } \\
\text { outstanding. }\end{array}$ & .197 & .132 & .158 & .865 & .002 \\
\hline & $\begin{array}{l}\text { My supervisor will give me special recognition if my } \\
\text { work performance is especially good. }\end{array}$ & .187 & .087 & .165 & .733 & .046 \\
\hline & $\begin{array}{l}\text { My supervisor will increase my job responsibilities if I } \\
\text { am performing well in my job. }\end{array}$ & .223 & .097 & .175 & .753 & .076 \\
\hline \multirow[t]{5}{*}{ Time Availability } & $\begin{array}{l}\text { During the past three months, my work load was too } \\
\text { heavy to spend time on developing new ideas. }\end{array}$ & .175 & .045 & -.02 & .041 & .789 \\
\hline & $\begin{array}{l}\text { I feel that I am always working with time constraints } \\
\text { on my job. }\end{array}$ & .006 & .087 & .03 & .05 & .763 \\
\hline & Eigenvalues & .554 & 2.056 & 1.534 & 1.364 & 1.564 \\
\hline & Cumulative (\%) & 26.98 & 38.45 & 47.45 & 55.45 & 63.57 \\
\hline & Cronbach's Alpha & .818 & .842 & .796 & .921 & .753 \\
\hline
\end{tabular}




\subsubsection{Perceived Organizational Performance}

In this study, researchers have extracted three components named as: (1) market performance (2) and financial performance (3) innovation performance.

Table 4 Factor analysis results for variables of organizational performance

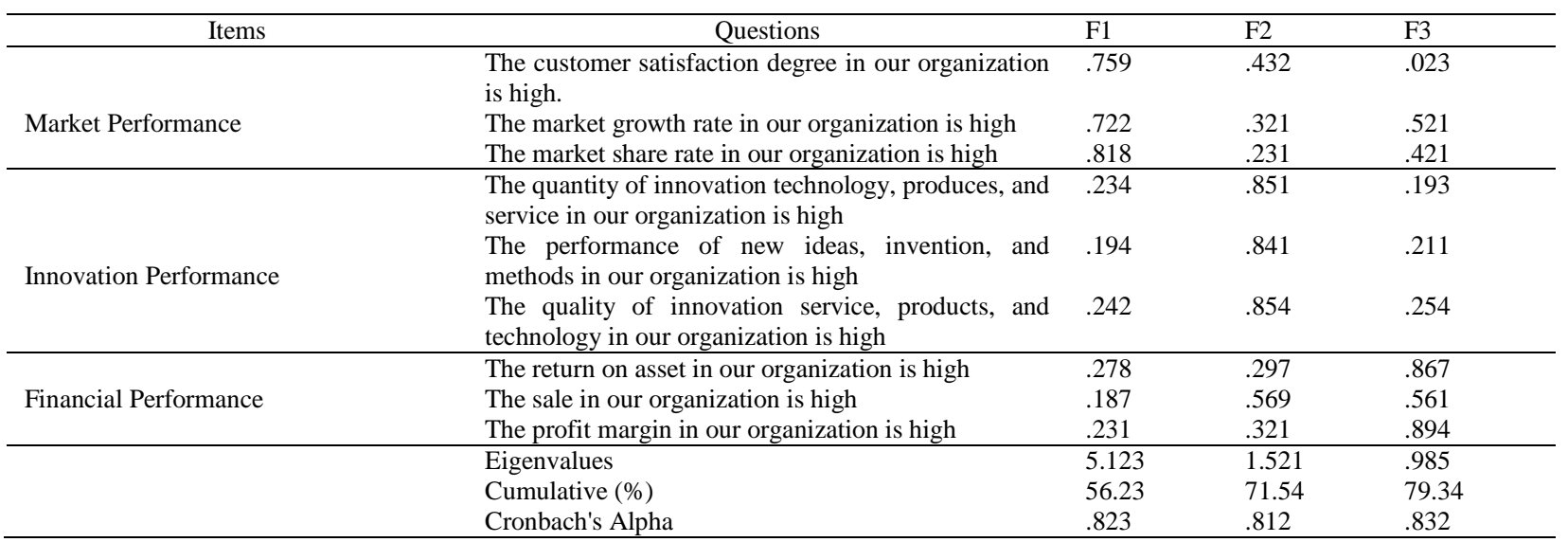

Table 5 Correlation analysis of research

\begin{tabular}{|c|c|c|c|c|c|c|c|c|c|c|c|c|c|c|}
\hline No. & Items & 1 & 2 & 3 & 4 & 5 & 6 & 7 & 8 & 9 & 10 & 11 & 12 & 13 \\
\hline 1 & $\begin{array}{l}\text { Years in Current } \\
\text { Work+ }\end{array}$ & 1.000 & & & & & & & & & & & & \\
\hline 2 & Innovativeness & -0.023 & 1.000 & & & & & & & & & & & \\
\hline 3 & Proactiveness & 0.051 & $.428 * *$ & 1.000 & & & & & & & & & & \\
\hline 4 & Risk Taking & 0.003 & $.232 * *$ & $.095^{*}$ & 1.000 & & & & & & & & & \\
\hline 5 & Work Discretion & 0.065 & $.177 * *$ & $.187 * *$ & 0.061 & 1.000 & & & & & & & & \\
\hline 6 & Time vailabity & 0.073 & $.255^{* *}$ & $.327 * *$ & $.168 * *$ & $.240 * *$ & 1.000 & & & & & & & \\
\hline 7 & Rewards & 0.008 & $.329 * *$ & $.354^{* *}$ & $.117 * *$ & $.234 * *$ & $.423 * *$ & 1.000 & & & & & & \\
\hline 8 & Management Support & -0.01 & $.134 * *$ & $.226 * *$ & $.134 * *$ & $.246^{* *}$ & $.394 * *$ & $.327 * *$ & 1.000 & & & & & \\
\hline 9 & $\begin{array}{l}\text { Organizational } \\
\text { boundaries }\end{array}$ & -0.081 & 0.045 & 0.026 & $.166^{* *}$ & $.133 *$ & 0.019 & 0.024 & 0.077 & 1.000 & & & & \\
\hline 10 & Financial Performance & 0.043 & $.089 *$ & $.195^{* *}$ & 0.075 & $.196 * *$ & $.134 * *$ & $.145^{* *}$ & $.254 * *$ & -0.054 & 1.000 & & & \\
\hline 11 & Market Performance & 0.061 & $.087 *$ & $.223 * *$ & 0.084 & $.211 * *$ & $.266 * *$ & $.202 * *$ & $.306 * *$ & -0.022 & $.832 * *$ & 1.000 & & \\
\hline 12 & $\begin{array}{l}\text { Innovation } \\
\text { Performance }\end{array}$ & $.137 * *$ & $.173 * *$ & $.367 * *$ & 0.021 & $.233 * *$ & $.432 * *$ & $.268 * *$ & $.349 * *$ & -0.078 & $.476^{* *}$ & $.587^{* *}$ & 1.000 & \\
\hline 13 & $\begin{array}{l}\text { Organizational } \\
\text { Support }\end{array}$ & $.171 * *$ & $.492 * *$ & -0.076 & $.351 * *$ & $.577 * *$ & $.352 * *$ & $.413 * *$ & $.263 * *$ & $.132 * *$ & 0.031 & $.432 * *$ & $.233^{* *}$ & 1.000 \\
\hline & Mean & 2.365 & 4.138 & 4.109 & 3.179 & 3.4848 & 3.5475 & 4.022 & 3.6967 & 3.213 & 4.92 & 5.188 & 4.6437 & 4.382 \\
\hline . & Std. Dev & 1.3265 & .55639 & .59525 & .80234 & .54368 & .60423 & .57345 & .67644 & .71914 & 1.05189 & .96625 & 1.64358 & .88631 \\
\hline
\end{tabular}

+ The tabulation of this variable was in the range of 5 to 5 , starting at 5 years.

(*) Correlation is significant at the 0.05 level (2-tailed).

$(* *)$ Correlation is significant at the 0.01 level (2-tailed). 
Table 6 Regression analysis results

\begin{tabular}{|c|c|c|c|c|c|c|c|}
\hline \multicolumn{2}{|l|}{ Performance of $\rightarrow$} & \multicolumn{2}{|l|}{ Financial } & \multicolumn{2}{|l|}{ Market } & \multicolumn{2}{|c|}{ Innovation } \\
\hline & & M1 & M2 & M1 & M2 & M1 & M2 \\
\hline Control Variable & $\begin{array}{l}\text { Years in current } \\
\text { work }\end{array}$ & .043 & .031 & .039 & & $.19^{* *}$ & $.152 * *$ \\
\hline \multirow{5}{*}{$\begin{array}{l}\text { Corporate } \\
\text { Entrepreneurs' } \\
\text { Characteristics }\end{array}$} & Risk taking & .062 & .051 & .073 & .052 & .001 & -.031 \\
\hline & Innovativeness & .006 & -.031 & -.056 & $-.086^{*}$ & .043 & -.047 \\
\hline & Proactiveness & $.192 * * *$ & $.156^{* *}$ & $.261^{* * *}$ & $.246^{* * *}$ & $.321 * * *$ & $.245^{* * * *}$ \\
\hline & Work discretion & & .003 & & .031 & & .032 \\
\hline & $\begin{array}{l}\text { Organizational } \\
\text { boundaries }\end{array}$ & & $.133^{* *}$ & & $.124 * *$ & & $.091 *$ \\
\hline \multirow{6}{*}{$\begin{array}{l}\text { Corporate } \\
\text { Entrepreneurial } \\
\text { Environment }\end{array}$} & Time availability & & -.079 & & -.075 & & $-.123 * *$ \\
\hline & $\begin{array}{l}\text { Management } \\
\text { support }\end{array}$ & & .031 & & $.134 *$ & & $.221 * * *$ \\
\hline & Rewards & & $.174^{* * * *}$ & & $.178^{* * * *}$ & & $.191 * * *$ \\
\hline & $\mathrm{F}$ & $5.342 * * *$ & $6.452 * * *$ & $11.333^{* * * *}$ & $11.364 * * *$ & & 22.477 *** \\
\hline & R Square $\left(\mathrm{R}^{2}\right)$ & .051 & .121 & .091 & .124 & & .452 \\
\hline & $\begin{array}{ll}\text { Adjusted } & R \\
\text { Square }\left(\Delta R^{2}\right) & \end{array}$ & & .088 & & .186 & & .262 \\
\hline
\end{tabular}

\subsection{DISCUSSION}

Three individual characteristics of middle managers were used to analysis the factor which including: proactiveness, innovativeness, and risk taking. With regard to the outcomes (see table 6) we concluded that amid the three dependent variables (perceived organizational performance: market, financial, and also innovation performance), there is an important positive association between proactiveness and perceived organizational performance. Therefore, the hypothesis 1a was supported.

As the result shows, hypothesis $1 \mathrm{~b}$ was relatively supported in that the relationship between corporate entrepreneurs with take risk features is not important while they have positively associated with perceived organizational performance. Hence, this research concludes that several middle managers in Iran have not risked taking personalities to innovate or that several organizations don't reach to this level therefore, they don't have too much freedom.

There is no support for the result of hypothesis 1c. There is a positive association between the corporate entrepreneur with innovativeness and perceived organizational performance. Whereas, J. Mehrabi, Gharakhani, and Farahmandian (2012) recommended that "the increasing attention in the research of entrepreneurship is a reaction to the acceptance that such action is able to result in enhanced operation in constituted organizations", we obtained opposite of the result. The relation for market performance is negatively and important, in this case; in this case, we can conclude that having innovative middle managers is difficult and also having good market performance at the same time (Larcker, Richardson, \& Tuna, 2007).

The result demonstrates that hypothesis $2 \mathrm{a}$ is supported, in which management support is a positive association with innovation performance and market performance, it means that the corporate entrepreneurs do more innovation when the companies have more management support (Miroshnik, 2007). As the result of this study, hypothesis $2 \mathrm{~b}$ was relatively supported in that work discretion is a positive association with perceived organizational performance (innovation performances, financial and market) but not significantly.

The result shows, hypothesis $2 \mathrm{c}$ was supported in that rewards are in positive association with financial performances, innovation and market, it means that with additional rewards, the companies will then have market, higher financial and innovation performances. Based on C. J. Shieh (2008) study, the results of H2a, H2b, and H2c show that the types of CE activities a firm pursues is affected by internal organizational components. Zhu and Jiao (2013) converge on five components: (1) Time availability; (2) Organizational boundaries; (3) Rewards; (4) Management support; and (5) Work discretion.

Perceived organizational performance and time availability have a negative relationship together (P. A. Stanwick \& S. A. Stanwick, 1998; Stites \& Michael, 2011; Tai, Huang, \& Chen, 2005; Tseng, 2010; Turban \& Greening, 1997; J. L. Walls, 2012; C. P. M. Wilderom, P. T. van den Berg, \& U. J. Wiersma, 2012; Wu, 2006; Xie \& Ye, 2008). Consequently, we conclude that middle managers may have a limited time to design new strategies for Iran's companies when companies give additional work, time restrictions, and standard operating processes and documented working procedures.

There is a positively associated with perceived organizational performance and organizational boundaries and significance. Therefore, to have better performance of middle managers, the firms must clear the standard operating processes and procedures.

\subsection{CONCLUSION}

To collect data, in this study questionnaire has been used. The data were collected via mail survey from middle managers of firms which are listed in Iran's lists of top companies (Panayides \& Lun, 2009),(Z. Mehrabi, Firouzbakhsh, \& Jafarpour, 2012).In terms of CE relations have a numerous implications for organizational elements, perceived organizational support, corporate entrepreneur characteristics, and perceived organizational performance(P. A. Stanwick \& S. D. Stanwick, 1998); (Stites \& Michael, 2011). The result present, hypothesis 1a 
is supported. Therefore, leaders understand that employees that involving a proactive personality can be more initiative to lead to successful performance of the company (Kiryukhin, Miroshnik, Maguskin, \& Delemen, 2013)

On the other hand, if a firm lacks organizational support like caring employees' goodness, valuing employees' contributions, appreciating employees' extra efforts, noticing the extraordinary performance, caring general satisfaction, concerning about employees, taking pride in employees' accomplishments. Findings of this research show that corporate entrepreneurship does not only mediate the relations between perceived organizational support, and perceived organizational performance $(\mathrm{H} 1)$, but also mediates the relations between corporate entrepreneurship characteristics. Just as social exchange theory states, employees who perceive their organization as supportive feel obligated to be beneficial to the organization. In this kind of positive climate, which involves management support and work discretion, employees are more proactive and innovative, and they contribute creative ideas for corporate entrepreneurship.

Proactiveness has been important whereas evaluating and selecting process for staff position in firms (Turban \& Greening, 1997), (Judith L Walls, Berrone, \& Phan, 2012), (C. P. Wilderom, P. T. van den Berg, \& U. J. Wiersma, 2012). The present result indicates that hypothesis $1 \mathrm{~b}$ has not been supported but, variable of corporate entrepreneurs with variable of risk taking characteristics are positively linked with variable of innovation performance (Barron \& Qu, 2014), (Belaid Rettab, Brik, \& Mellahi, 2009), (W. Shieh, Bao, \& Tang, 2008). Thus, lack of middle managers risk taking characteristics to innovate in Iran's companies. Therefore, middle managers required to have more courage to develop their companies.

Hypothesis 2 a result show that, management support is positively and significantly has a relationship with perceived organizational performance. Hypothesis $2 \mathrm{~b}$ result shows that, work discretion is not significantly having a relationship with innovation performance but positively. Thus, rewards are positively linked with performances of financial, market, and innovation. Hypothesis $2 \mathrm{c}$ result shows that, organizational boundaries are significantly linked with performances of financial, market, and also innovation. However, results indicate that relationship between time availability and perceived organizational performance is not significant.

Result shows that hypothesis $2 \mathrm{~d}$ was not supported, because companies have standard operating procedures, time constraints, documented working processes, and heavier workloads. Thus, middle managers do not have more enthusiasm and time for innovation. The current result closely is similar to the situation in some of Iran's organizations that facing all above issues in their companies. Therefore, the companies required to have more time availability, work knowledge, rewards, management support, and organizational boundaries which can allow corporate entrepreneurs to be more innovativeness and also deliver high quality of financial performances.

\section{References}

Ambrose, M. L., \& Schminke, M. (2003). Organization structure as a moderator of the relationship between procedural justice, interactional justice, perceived organizational support, and supervisory trust. Journal of Applied psychology, 88(2), 295.

Antoncic, B., \& Hisrich, R. D. (2004). Corporate entrepreneurship contingencies and organizational wealth creation. Journal of Management Development, 23(6), 518550 .

Armesh, H., Wei, C. C., Ghalandarzehie, K., Sargolzaie, A., \& Kahrazeh, Y. (2014). Impact of Organization and Environment Components on Corporate Entrepreneurship and Firm Performance: Mediating Role of Corporate Entrepreneurship Exploring on.

Azulay, I., Lerner, M., \& Tishler, A. (2002). Converting military technology through corporate entrepreneurship. Research Policy, 31(3), 419-435. doi: Pii S00487333(01)00117-2

Barron, O. E., \& Qu, H. (2014). Information Asymmetry and the Ex Ante Impact of Public Disclosure Quality on Price Efficiency and the Cost of Capital: Evidence from a Laboratory Market. The Accounting Review, 89(4), 1269-1297.

Chao, G., Cheng, P., \& Zheng, S. Y. (2011). The Study on the Relationship of Corporate Social Performance, Organizational Identification and Job Involvement Proceedings of the 7th Euro-Asia Conference on Environment and Csr: Technological Innovation and Management Science Session, Pt Ii, $208-215$.

Chen, M. H., \& Cangahuala, G. (2010). Corporate Entrepreneurship Environment and Organizational Performance in Technology Manufacturing Sector. Picmet 2010: Technology Management for Global Economic Growth.

Chen, Y., Tang, G. Y., Jin, J. F., Xie, Q. H., \& Li, J. (2014). CEOs' Transformational Leadership and Product Innovation Performance: The Roles of Corporate Entrepreneurship and Technology Orientation. Journal of Product Innovation Management, 31, 2-17. doi: Doi 10.1111/Jpim.12188

Choi, Y., \& Yu, Y. N. (2014). The Influence of Perceived Corporate Sustainability Practices on Employees and Organizational Performance. Sustainability, 6(1), 348364. doi: Doi 10.3390/Su6010348

Dai, W. Q., \& Lin, Q. (2012). On Strategies for Clutered Firm's Upgrading and Development under Dynamic Environment: From the Perspective of Corporate Entrepreneurship. 2012 2nd International Conference on Applied Social Science (Icass 2012), 4, 250-254.

Eisenberg, D. M., Davis, R. B., Ettner, S. L., Appel, S., Wilkey, S., Van Rompay, M., \& Kessler, R. C. (1998). Trends in alternative medicine use in the United States, 1990-1997: results of a follow-up national survey. Jama, 280(18), 1569-1575.

Evolving Corporate Entrepreneurship Strategy: Technology Incubation at Philips. (2010). Research-Technology Management, 53(3), 68-68.

Fang, S. R., Huang, C. Y., \& Huang, S. W. L. (2010). Corporate social responsibility strategies, dynamic capability and organizational performance: Cases of top Taiwan-selected benchmark enterprises. African Journal of Business Management, 4(1), 120-132.

Felicio, J. A., Couto, E., \& Caiado, J. (2013). Human capital, social capital and organizational performance: A structural modeling approach: Centre for Applied Mathematics and Economics (CEMAPRE), School of Economics and Management (ISEG), Technical University of Lisbon.

Felicio, J. A., Goncalves, H. M., \& Goncalves, V. D. (2013). Social value and organizational performance in non-profit social organizations: Social entrepreneurship, leadership, and socioeconomic Context effects. Journal of Business Research, 66(10), 2139-2146. doi: DOI 10.1016/j.jbusres.2013.02.040

Ford, S., Garnsey, E., \& Probert, D. (2010). Evolving corporate entrepreneurship strategy: technology incubation at Philips. $R$ \& D Management, 40(1), 81-90.

Gomez-Haro, S., Aragon-Correa, J. A., \& Cordon-Pozo, E. (2011). Differentiating the effects of the institutional environment on corporate entrepreneurship. Management Decision, 49(9-10), 1677-1693. doi: Doi 10.1108/00251741111183825

Gonzalez-Moreno, A., \& Saez-Martinez, F. J. (2009). Cooperation with universities and research institutions for corporate entrepreneurship activities: the influence of the technological intensity of the environment. Entrepreneurship and Growth in Local, Regional and National Economies: Frontiers in European Entrepreneurship, 231-253.

Haar, J. M., \& White, B. J. (2013). Corporate entrepreneurship and information technology towards employee retention: a study of New Zealand firms. Human Resource Management Journal, 23(1), 109-125. doi: DOI 10.1111/j.1748-8583.2011.00178.x

Handfield, R., Petersen, K., Cousins, P., \& Lawson, B. (2009). An organizational entrepreneurship model of supply management integration and performance outcomes. International Journal of Operations \& Production Management, 29(1-2), 100-126. doi: Doi 10.1108/01443570910932011

Hayton, J. C. (2005). Competing in the new economy: The effect of intellectual capital on corporate entrepreneurship in high-technology new ventures. R \& D Management, 35(2), 137-155. doi: DOI 10.1111/j.1467-9310.2005.00379.x

Hinz, V., \& Ingerfurth, S. (2013). Does Ownership Matter Under Challenging Conditions? On the relationship between organizational entrepreneurship and performance in the healthcare sector. Public Management Review, 15(7), 969-991. doi: Doi 10.1080/14719037.2012.757348 
Hochwarter, W. A., Kacmar, C., Perrewe, P. L., \& Johnson, D. (2003). Perceived organizational support as a mediator of the relationship between politics perceptions and work outcomes. Journal of Vocational Behavior, 63(3), 438-456.

Holt, D. T., Rutherford, M. W., \& Kuratko, D. F. (2010). Advancing the field of family business research: Further testing the measurement properties of the F-PEC. Family Business Review, 23(1), 76-88.

Hornsby, J. S., Kuratko, D. F., \& Zahra, S. A. (2002). Middle managers' perception of the internal environment for corporate entrepreneurship: assessing a measurement scale. Journal of Business Venturing, 17(3), 253-273. doi: Doi 10.1016/S0883-9026(00)00059-8

Kearney, C., Hisrich, R. D., \& Antoncic, B. (2013). The Mediating Role of Corporate Entrepreneurship for External Environment Effects on Performance. Journal of Business Economics and Management, 14, S328-S357. doi: Doi 10.3846/16111699.2012.720592

Kiryukhin, A., Miroshnik, O., Maguskin, M., \& Delemen, I. (2013). Modeling and Observations of the Enthalpy, Pressure, Chloride, CO2 and Vertical Deformation Transient Change in the Mutnovsky Geothermal Field (Kamchatka, Russia). Paper presented at the Proceedings.

Kuratko, D. F., Hornsby, J. S., \& Covin, J. G. (2014). Diagnosing a firm's internal environment for corporate entrepreneurship. Business Horizons, 57(1), 37-47. doi: DOI 10.1016/j.bushor.2013.08.009

Larcker, D. F., Richardson, S. A., \& Tuna, I. (2007). Corporate governance, accounting outcomes, and organizational performance. Accounting Review, 82(4), 9631008. doi: DOI 10.2308/accr.2007.82.4.963

le Roux, T. (2014). The description of South African corporate communication practitioners that contribute to organisational performance. Public Relations Review, 40(2), 193-215. doi: DOI 10.1016/j.pubrev.2013.11.008

Leitao, J., \& Franco, M. (2011). Individual entrepreneurship capacity and small and medium enterprises (SME) performance: A human and organizational capital approach. African Journal of Business Management, 5(15), 6350-6365.

Lu, C. S., Lin, C. C., \& Tu, C. J. (2009). Corporate social responsibility and organisational performance in container shipping. International Journal of LogisticsResearch and Applications, 12(2), 119-132. doi: Doi 10.1080/13675560902749373

Martin-Rojas, R., Garcia-Morales, V. J., \& Bolivar-Ramos, M. T. (2013). Influence of technological support, skills and competencies, and learning on corporate entrepreneurship in European technology firms. Technovation, 33(12), 417-430. doi: DOI 10.1016/j.technovation.2013.08.002

Masterson, S. S., Lewis, K., Goldman, B. M., \& Taylor, M. S. (2000). Integrating justice and social exchange: The differing effects of fair procedures and treatment on work relationships. Academy Of Management Journal, 43(4), 738-748.

Mehrabi, J., Gharakhani, D., \& Farahmandian, A. (2012). The impact of corporate social responsibility on organizational performance. Life Science Journal-Acta Zhengzhou University Overseas Edition, 9(4), 2313-2318.

Mehrabi, Z., Firouzbakhsh, F., \& Jafarpour, A. (2012). Effects of dietary supplementation of synbiotic on growth performance, serum biochemical parameters and carcass composition in rainbow trout (Oncorhynchus mykiss) fingerlings. Journal Of Animal Physiology And Animal Nutrition, 96(3), 474-481.

Miroshnik, V. (2007). Organizational Culture and Corporate Performance of Japanese Companies: a Theoretical Model. Beyond Borders: New Global Management Development Challenges and Opportunities, 16, 589-595.

O'Connor, M.-F., Wellisch, D. K., Stanton, A. L., Eisenberger, N. I., Irwin, M. R., \& Lieberman, M. D. (2008). Craving love? Enduring grief activates brain's reward center. Neuroimage, 42(2), 969-972.

Olmedo-Cifuentes, I., \& Martnez-Leon, I. (2012). Organizational Learning and Corporate Reputation: Relations and Effects on Financial Performance. Proceedings of the 13th European Conference on Knowledge Management, 1 \& 2, 889-898.

Panayides, P. M., \& Lun, Y. V. (2009). The impact of trust on innovativeness and supply chain performance. International Journal of Production Economics, 122(1), $35-46$.

Parast, M. M., \& Adams, S. G. (2012). Corporate social responsibility, benchmarking, and organizational performance in the petroleum industry: A quality management perspective. International Journal of Production Economics, 139(2), 447-458. doi: DOI 10.1016/j.ijpe.2011.11.033

Rettab, B., Ben Brik, A., \& Mellahi, K. (2009). A Study of Management Perceptions of the Impact of Corporate Social Responsibility on Organisational Performance in Emerging Economies: The Case of Dubai. Journal of Business Ethics, 89(3), 371-390. doi: DOI 10.1007/s10551-008-0005-9

Rettab, B., Brik, A. B., \& Mellahi, K. (2009). A study of management perceptions of the impact of corporate social responsibility on organisational performance in emerging economies: the case of Dubai. Journal Of Business Ethics, 89(3), 371-390.

Rhoades, L., Eisenberger, R., \& Armeli, S. (2001). Affective commitment to the organization: the contribution of perceived organizational support. Journal Of Applied Psychology, 86(5), 825 .

Rhoades, M. W., Reinhart, B. J., Lim, L. P., Burge, C. B., Bartel, B., \& Bartel, D. P. (2002). Prediction of plant microRNA targets. cell, 110(4), 513-520. Rich, B. L., Lepine, J. A., \& Crawford, E. R. (2010). Job engagement: Antecedents and effects on job performance. Academy of management journal, 53(3), 617-635.

Ring, J. K. (2011). The Effect of Perceived Organizational Support and Safety Climate on Voluntary Turnover in the Transportation Industry. International Journal of Business Research and Management, 1(3), 156-168.

Shanock, L. R., \& Eisenberger, R. (2006). When supervisors feel supported: relationships with subordinates' perceived supervisor support, perceived organizational support, and performance. Journal of Applied psychology, 91(3), 689.

Shieh, C. J. (2008). Effect of Corporate Compensation Design on Organizational Performance. Social Behavior and Personality, 36(6), 827-839. doi: DOI $10.2224 / \mathrm{sbp} .2008 .36 .6 .827$

Shieh, W., Bao, H., \& Tang, Y. (2008). Coherent optical OFDM: theory and design. Optics Express, 16(2), 841-859.

Stanwick, P. A., \& Stanwick, S. A. (1998). The relationship between corporate social performance, and organizational size, financial performance, and environmental performance: An empirical examination. Journal of Business Ethics, 17(2), 195-204. doi: Doi 10.1023/A:1005784421547

Stanwick, P. A., \& Stanwick, S. D. (1998). The relationship between corporate social performance, and organizational size, financial performance, and environmental performance: An empirical examination. Journal of Business Ethics, 17(2), 195-204.

Stites, J. P., \& Michael, J. H. (2011). Organizational Commitment in Manufacturing Employees: Relationships With Corporate Social Performance. Business \& Society, 50(1), 50-70. doi: Doi 10.1177/0007650310394311

Tai, D. W. S., Huang, C. E., \& Chen, H. C. (2005). An empirical research on the relationships between corporate transformation, human resource strategy and organisational performance for small and medium-sized firms in Taiwan. 4th Asia-Pacific Forum on Engineering and Technology Education, Forum Proceedings, $187-190$

Tseng, S. M. (2010). The correlation between organizational culture and knowledge conversion on corporate performance. Journal of Knowledge Management, 14(2), 269-284. doi: Doi 10.1108/13673271011032409

Turban, D. B., \& Greening, D. W. (1997). Corporate social performance and organizational attractiveness to prospective employees. Academy of Management Journal, 40(3), 658-672. doi: Doi 10.2307/257057

Walls, J. L. (2012). Corporate Social Responsibility and Business Performance: Theories and Evidence about Organizational Responsibility. Environment and Planning C-Government and Policy, 30(5), 941-942. doi: Doi 10.1068/C3005rev

Walls, J. L., Berrone, P., \& Phan, P. H. (2012). Corporate governance and environmental performance: is there really a link? Strategic Management Journal, 33(8), 885-913.

Wilderom, C. P., van den Berg, P. T., \& Wiersma, U. J. (2012). A longitudinal study of the effects of charismatic leadership and organizational culture on objective and perceived corporate performance. The Leadership Quarterly, 23(5), 835-848.

Wilderom, C. P. M., van den Berg, P. T., \& Wiersma, U. J. (2012). A longitudinal study of the effects of charismatic leadership and organizational culture on objective and perceived corporate performance. Leadership Quarterly, 23(5), 835-848. doi: DOI 10.1016/j.leaqua.2012.04.002

Wu, C. F. (2006). The study of the relations among ethical considerations, family management and organizational performance in corporate governance. Journal of Business Ethics, 68(2), 165-179. doi: DOI 10.1007/s10551-006-9063-z

Xie, W. H., \& Ye, D. (2008). An Empirical Research on the Relationships between Corporate Culture, Organizational Flexibility and Enterprise Performance Proceedings of the International Conference on Information Management, Innovation Management and Industrial Engineering, II, 325-328. doi: Doi 10.1109/Iciii.2008.305 
Yang, H., Xu, E. M., \& Lu, Y. (2012). Organizational Slacks and Corporate Social Performance of Listed Companies: The Role of State-owned Holding. 2012 International Conference on Management Science \& Engineering, 445-452.

Zahra, S. A. (1993). Environment, Corporate Entrepreneurship, and Financial Performance - a Taxonomic Approach. Journal of Business Venturing, 8(4), 319-340. doi: Doi 10.1016/0883-9026(93)90003-N

Zhao, S., Xu, W., Jiang, W., Yu, W., Lin, Y., Zhang, T., . . Li, H. (2010). Regulation of cellular metabolism by protein lysine acetylation. Science, 327(5968), 10001004.

Zhu, S., \& Jiao, H. (2013). Organizational structure and corporate performance: insights from 6,065 listed corporations. Chinese Management Studies, 7(4), 535-556. doi: Doi 10.1108/Cms-09-2013-0174 